\title{
REDUCTION AND INTERNAL FIXATION OF COMPLEX FRACTURES OF THE ODONTOID BY THE TRANSORAL APPROACH
}

\author{
REDUÇÃO E OSTEOSSÍNTESE DE FRATURA COMPLEXA DO ODONTOIDE POR \\ VIA TRANSORAL
}

\section{REDUCCIÓN Y FIJACIÓN INTERNA DE FRACTURAS COMPLEJAS DE LA ODONTOIDES POR LA VÍA TRANSORAL}

\author{
Geraldo de Sá Carneiro, ${ }^{1}$ Deoclides lima Bezerra Júnior, ${ }^{1}$ Juliano Rodrigues Chaves, ${ }^{1}$ Saul Cavalcanti de Medeiros Quinino, ${ }^{1}$ \\ Aline FigueIRAS da Trindade ${ }^{2}$ \\ 1. Hospital da Restauração, Spine Department of the Neurosurgery Service, Recife, PE, Brazil. \\ 2. Universidade de Pernambuco, School of Medical Sciences, Recife, PE, Brazil.
}

\begin{abstract}
Type II odontoid fractures with irreducible posterior displacement are uncommon, and can cause spinal cord compression, respiratory failure and even death. Treatment is usually surgical, with transoral decompression and posterior fusion or with reduction and fusion of C1-C2 by the transoral approach. We describe a case of type II odontoid fracture with irreducible posterior atlantoaxial dislocation that was treated exclusively by the transoral approach with osteosynthesis of the odontoid, thus preserving functional segmental mobility. Level of Evidence III; therapeutic study.
\end{abstract}

Keywords: Atlanto-axial joint; Arthrodesis; Fracture fixation, internal; Odontoid process; Spinal injuries.

\section{RESUMO}

As fraturas do odontoide tipo /l com deslocamento posterior irredutível não são comuns e podem causar compressão medular, insuficiência respiratória e até óbito. O tratamento habitualmente é cirúrgico, com descompressão transoral e fusão posterior, ou com a redução e fusão C1-C2 pela via transoral. Descrevemos um caso de fratura do odontoide tipo II, com deslocamento atlantoaxial posterior irredutível, que foi tratado exclusivamente por via transoral, com a osteossíntese do odontoide, preservando, assim, a mobilidade funcional segmentar. Nível de Evidência III; Estudo terapêutico

Descritores: Articulação atlantoaxial; Artrodese; Fixação interna de fraturas; Processo odontoide; Traumatismos da coluna vertebral.

\section{RESUMEN}

Las fracturas tipo II de la odontoides con desplazamiento posterior irreductible son poco comunes y pueden causar compresión de la médula espinal, insuficiencia respiratoria e incluso la muerte. El tratamiento suele ser quirúrgico con descompresión transoral y fusión posterior o con reducción y fusión de C1-C2 por vía transoral. Se describe un caso de fractura tipo II de la odontoides con luxación atlantoaxial posterior irreductible que fue tratada exclusivamente por vía transoral con osteosíntesis de la odontoides, preservando así la movilidad segmentaria funcional. Nivel de Evidencia III; Estudio terapéutico.

Descriptores: Articulación atlantoaxoidea; Artrodesis; Fijación interna de fracturas; Apófisis odontoides; Traumatismos vertebrales.

\section{INTRODUCTION}

Odontoid fractures are relatively common, corresponding to $20 \%$ of all acute cervical fractures. However, fracture of the odontoid process with posterior atlantoaxial dislocation is uncommon. Patients with this type of injury rarely survive. Its occurrence is not well known in the literature, but it is believed that there are two incidence peaks: one in young people and another in people aged 70 and older. ${ }^{1}$

These fractures are generally realigned with cervical traction. However, those cases that reduction is not achieved are a challenge. In general, anterior decompression through transoral approach is proposed, with subsequent fusion or decompression and anterior fusion C1-C2 with specific instruments..$^{2-4}$

We report another technique, in which we carry out reduction and osteosynthesis of the fracture using a transoral approach.

\section{METHODS}

This is a case report of a surgical therapeutic approach in a patient with a type II odontoid fracture and irreducible posterior displacement. An Informed Consent Form was duly signed by the patient. This study was not submitted to the Research Ethics Committee.

\section{CASE REPORT}

We report a case of a 34 year-old patient, male, healthy, not smoker, non osteoporotic, who was victim of motorcycle accident. On admission, he complained of neck pain and retroauricular pain. Neurological examination revealed no abnormalities and there was no associated trauma. Imaging tests showed a fractured odontoid Type II associated with posterior atlantoaxial dislocation and 
involvement of the spinal canal. (Figure 1) Reduction by cervical traction was attempted, without success. A combined transoral approach to decompression followed by posterior cervical fusion was designed.

The patient was taken to the operating room and initially approached by transoral access. We observed the fracture line, where the odontoid process was ankylosed and dislocated posteriorly. After osteotomy performed with the drill in the fracture line, the head was slightly bent and complete reduction of the posterior dislocation of the odontoid process was observed. As the osteotomy resulted in a gap, we removed the iliac graft and placed it between the odontoid and $\mathrm{C} 2$ body. Fixation of the fracture was then performed using a mini-plate $2.4 \mathrm{~mm}$. (Figure 2, 3, 4 and 5)

The patient had an uneventful postoperative period and was discharged with instructions to wear a cervical collar for 6 weeks. Patient is now in the twenty-third month of follow-up, with no complaints of pain and with established fusion and cervical mobility preserved. (Figure 6)

\section{DISCUSSION}

Type II odontoid fracture with irreducible atlantoaxial dislocation although uncommon, can be associated with complex deformities of the craniocervical junction and represents a potential risk for neurological and medical complications such as cervical myelopathy, respiratory failure and even death. ${ }^{5,6}$

The consensus is that these fractures should be treated surgically. In these cases, the posterior cervical approach is commonly used and involves higher morbidity and - in some cases - the inability to completely reduce the fracture..$^{3,4,6,7} \mathrm{Fa}$ Jing Liu et al.

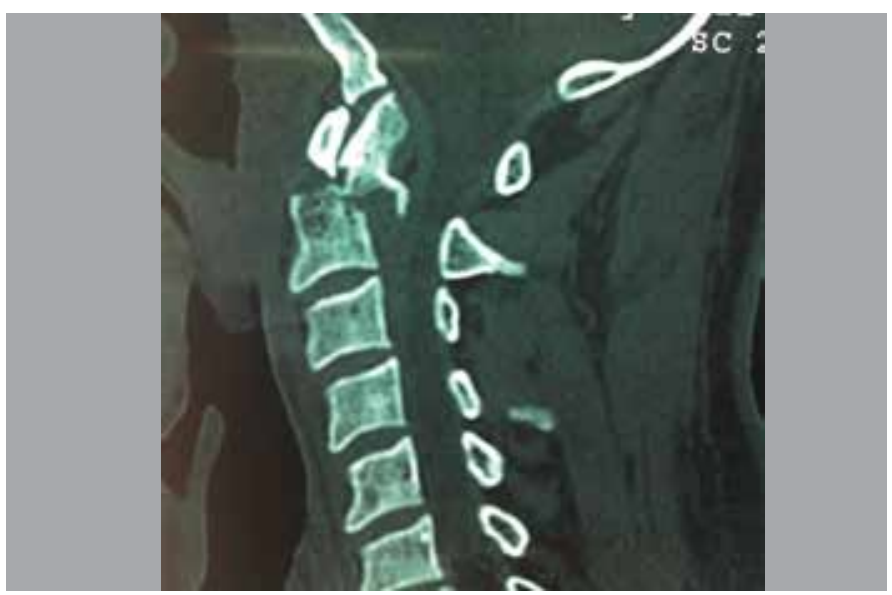

Figure 1. Sagittal CT scan cut showing the odontoid Type II fracture with posterior atlantoaxial dislocation.

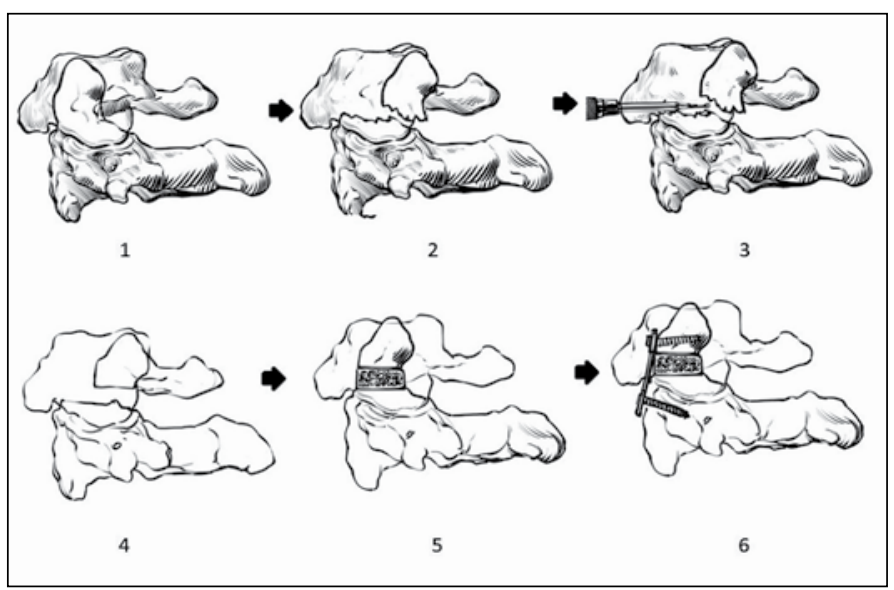

Figure 2. Step by step sketch of the surgical operation.

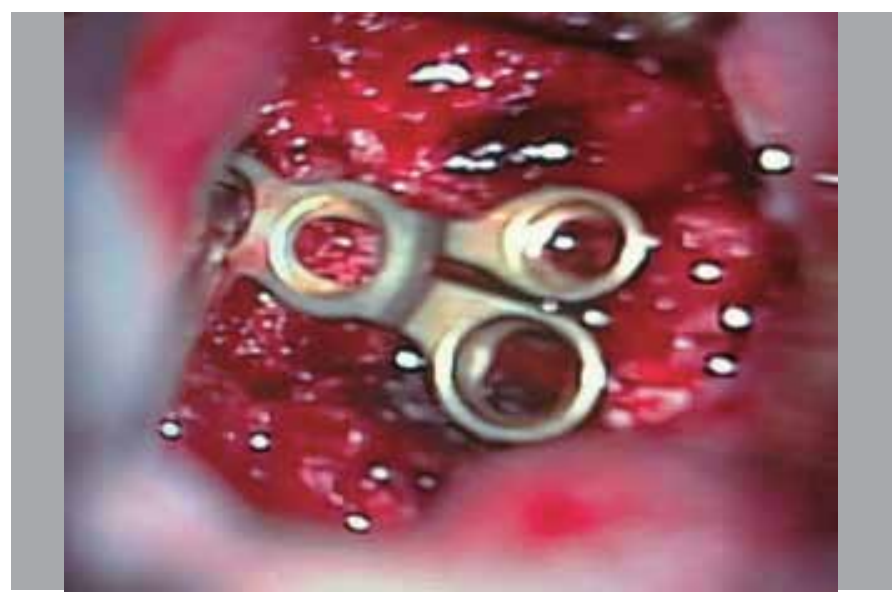

Figure 3. Intraoperative image of mini-plate $2.4 \mathrm{~mm}$ used.

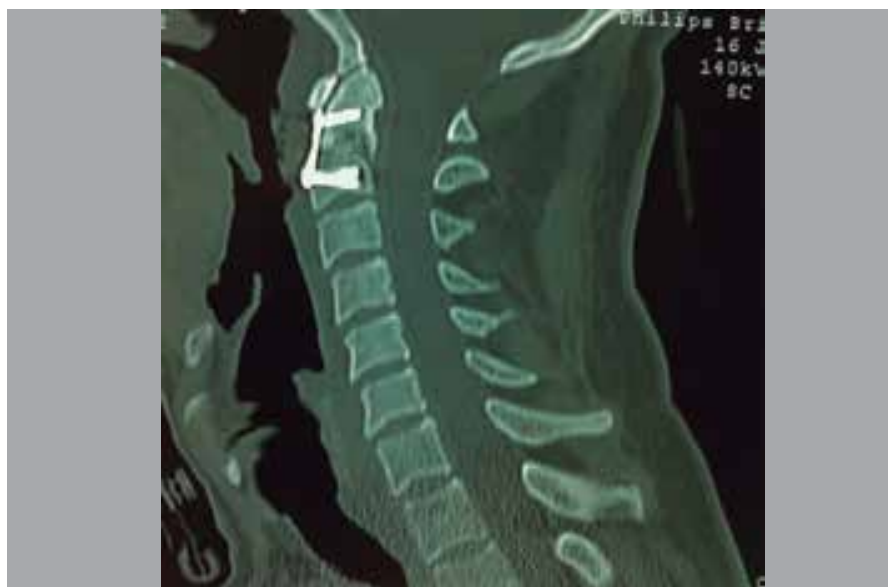

Figure 4. Sagittal CT scan showing fracture osteosynthesis, graft positioned between the odontoid process and body $\mathrm{C} 2$ and good cervical alignment.

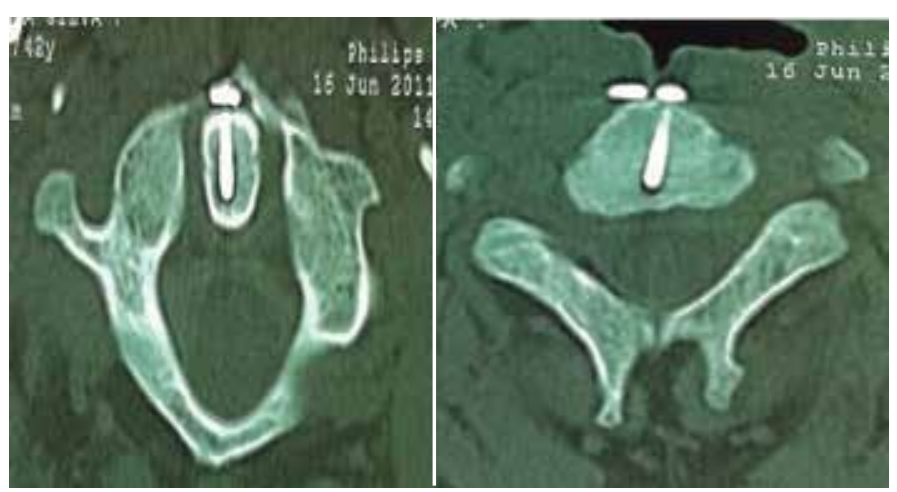

Figure 5. Axial CT scan showing well positioned screws on the odontoid process and the body of $\mathrm{C} 2$.

in 2005 described an interesting option. They developed a plate implanted by the transoral approach (TARP System), which enabled reduction and C1-C2 stabilization with a good fusion rate. ${ }^{2}$ In 2009, an artificial atlantodens joint was designed in the laboratory that could also be used in these patients, preserving cervical mobility. ${ }^{5}$

We report another alternative for the treatment of Type II odontoid fractures with posterior irreducible displacement. Instead of fusing $\mathrm{C} 1-\mathrm{C} 2$, we performed osteosynthesis of $\mathrm{C} 2$ by the transoral approach. Thus, we managed to realign the fracture, stabilize it, ensure preservation of cervical mobility, and reduce morbidity and surgical time in non-osteoporotic and non-smoker patients. 

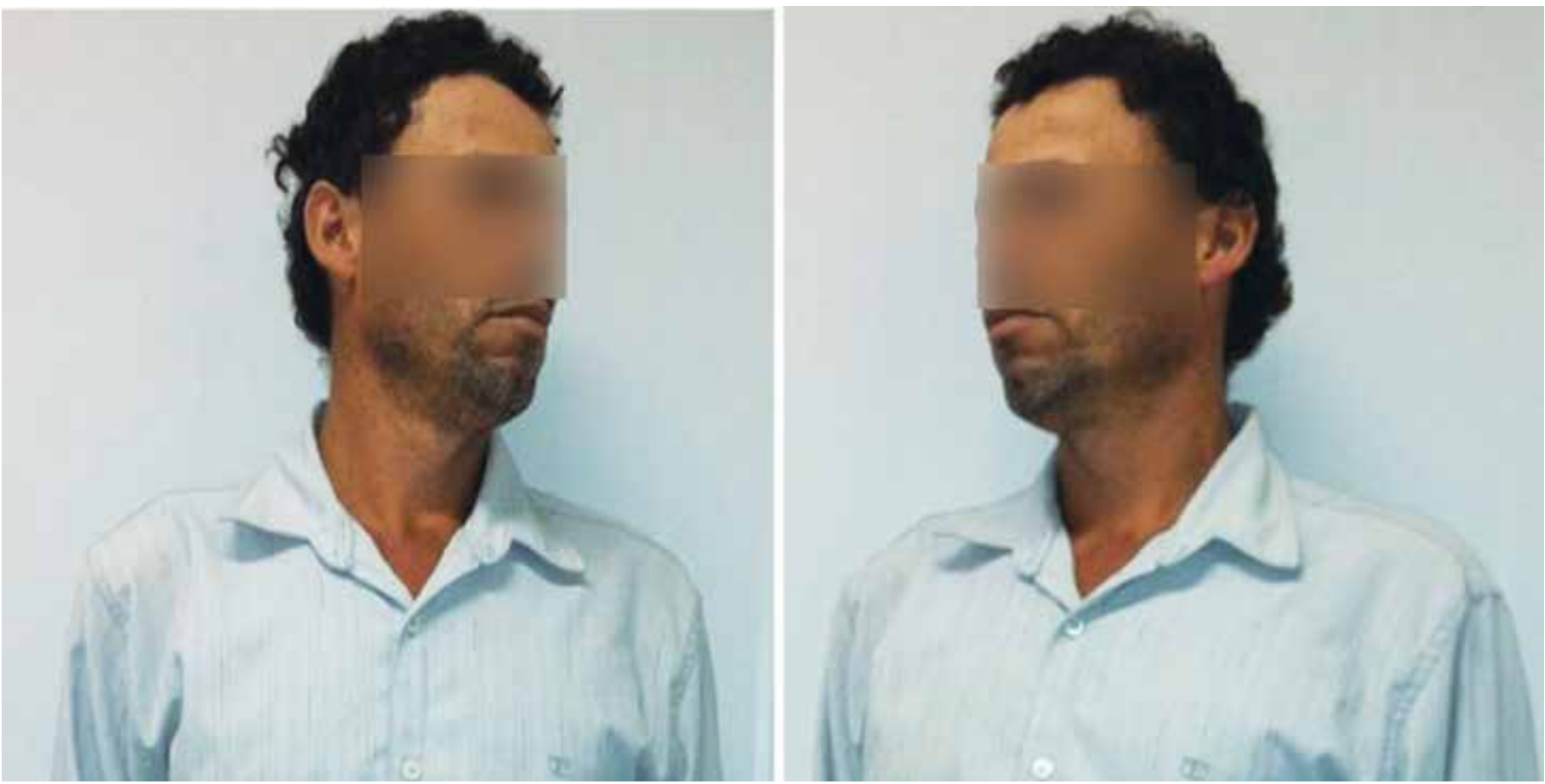

Figure 6. Cervical mobility preserved.

\section{CONCLUSIONS}

We conclude that the reduction and osteosynthesis of the odontoid fracture with irreducible posterior displacement through the transoral approach is feasible, safe and effective in non-osteoporotic young patients without comorbidities.

All authors declare no potential conflict of interest related to this article.

CONTRIBUTION OF THE AUTHORS: This manuscript, which is a uni-institutional study, has five authors. Each author made significant individual contributions to this manuscript. DLBJ (0000-0002-6493-350X)* was the main contributor in the writing of the manuscript. AFT (0000-0003-3974-8246)* was responsible for its translation into English and Spanish, editing and production of the images. GSC (0000-0002-5518-317X)* was the chief surgeon. DLBJ, JRC (0000-0001-7919-7384)* and SCMQ (0000-0001-9540-0020** were the assistant surgeons, and performed patient follow-up and gathering of clinical data. DLBJ and AFT carried out the bibliographic research and revision of the manuscript, and contributed to the intellectual concept of the study. *ORCID (Open Researcher and Contributor ID).

\section{REFERENCES}

1. Zhang K, Xu J, Wang Q, Wang G, Wu Z, Xia H, et al. Treatment of Dens Fractures With Posterior Atlantoaxial Dislocation With Transoral Atlantoaxial Dislocation With Transoral Atlantoaxial Reduction Plate Surgery. Spine (Phila Pa 1976). 2012;37(7):E451-5.

2. Yin Q, Ai F, Zhang K, Chang Y, Xia H, Wu Z, et al. Irreducible Anterior Atlantoaxial Dislocation: onde-stage treatment with a transoral atlantoaxial reduction plate fixation and fusion. Report of 5 cases and review of the literature. Spine (Phila Pa 1976). 2005;30(13):E375-81.

3. Ryken TC, Hadley MN, Walters BC, Aarabi B, Dhall SS, Gelb DE, et al. Management of Acute Combination Fractures of the Atlas and Axis in Adults. Neurosurgery. 2013;72(Suppl 2):151-8.

4. Ryken TC, Hadley MN, Walters BC, Aarabi B, Dhall SS, Gelb DE, et al. Management of Isolated Fractures of the Axis in Adults. Neurosurgery. 2013;72(Suppl 2):132-50.

5. Lu B, He JX, Zhao GC, Li HP, Wang D. Artificial atlanto-odontoid joint replacement through a transoral approach. Eur Spine J. 2009;18(1):109-17.

6. Wang S, Wang C, Yan M, Zhou H, Dang G. Novel Surgical Classification and Treatment Strategy for Atlantoaxial Dislocations. Spine (Phila Pa 1976). 2013;38(21):E1348-56.

7. Ai FZ, Yin QS, Xu DC, Xia H, Wu ZH, Mai XH. Transoral Atlantoaxial Reduction Plate Internal Fixation with Transoral Transpedicular or Articular Mass Screw of C2 for the Treatment of Irreducible Atlantoaxial Dislocation. Spine (Phila Pa 1976). 2011;36(8):E556-62. 